\title{
Pemenuhan Peraturan Pelabelan pada Produk IRTP di Kabupaten Kebumen
}

\author{
Fulfillment of Labeling Regulations on SMEs Products \\ in Kebumen District
}

\author{
Joko Hermanianto ${ }^{1)}$, Audia Ari Purwandani ${ }^{1)}$, dan Tjahja Muhandri ${ }^{1,2} *$ \\ ${ }^{1)}$ Departemen Ilmu dan Teknologi Pangan, Fakultas Teknologi Pertanian, Institut Pertanian Bogor, Bogor \\ ${ }^{2)}$ South East Asian Food and Agricultural Science and Technology (SEAFAST) Center, Institut Pertanian Bogor, Bogor
}

\begin{abstract}
Label regulations on food products must be adhered by food industries, including SMEs. The lack of awareness or understanding of SMEs on food labeling regulation causes non-complience of SMEe food products with regulations. The objective of this study was to evaluate the level of compliance with labeling regulations and consumer awareness of the labels on SMEs food products in Kebumen. Purposive sampling was used to determine the sample size. The data from product labels was analyzed by content analysis techniques on four distinct groups of elements, i.e. technical labeling, label writing, minimal information, and information that cannot be included. SMEs products that met writing labeling requirement were $27 \%$ and those that fulfilled the minimum label information requirement (excluding halal provision) were $40.81 \%$. The food product with halal label was only $18 \%$.
\end{abstract}

Keywords: food label, food regulation, SMEs, halal label

\begin{abstract}
Abstrak. Peraturan tentang label pada produk olahan pangan harus dipenuhi oleh semua industri pangan, termasuk industri rumah tangga pangan (IRTP). Kesadaran atau ketidaktahuan IRTP tentang peraturan label berdampak pada beredarnya produk pangan dengan label yang tidak sesuai dengan peraturan yang berlaku. Penelitian ini bertujuan untuk mengevaluasi tingkat pemenuhan peraturan pelabelan pada produk IRTP di Kebumen, Jawa Tengah. Metode yang digunakan adalah metode survei lapangan. Sampel ditentukan dengan menggunakan metode purposive sampling. Data label produk pangan dianalisis dengan teknik content analysis terhadap empat kelompok unsur, yaitu teknis pencantuman label, tulisan pada label, keterangan minimum, dan keterangan yang dilarang dicantumkan. Produk IRTP yang telah memenuhi persyaratan tulisan pada label ada $27 \%$ dan yang memenuhi persyaratan keterangan minimum label (di luar ketentuan halal) ada $40.81 \%$. Pencantuman label halal sesuai persyaratan baru mencapai $18 \%$.
\end{abstract}

Kata kunci: IRTP, Kebumen, label, pemenuhan persyaratan

Aplikasi Praktis. Penelitian ini berupaya mengungkap kondisi nyata di lapangan tentang pemenuhan
ketentuan label oleh Industri Rumah Tangga Pangan (IRTP) di Kabupaten Kabumen. Kondisi di
lapangan menunjukkan bahwa masih banyak IRTP yang belum memenuhi persyaratan tentang
pelabelan. Hasil riset diharapkan dapat menjadi data dasar bagi pengambil keputusan untuk merancang
program pembinaan bagi IRTP di Kabupaten Kebumen.

\section{PENDAHULUAN}

Industri pangan yang menghasilkan produk pangan yang dikemas eceran (produk retail) wajib mencantumkan label pada kemasannya. Hal ini berdasarkan Peraturan BPOM Nomor 31 Tahun 2018 tentang Label Pangan Olahan (BPOM 2018) bahwa setiap orang yang memproduksi pangan olahan di dalam negeri untuk diperdagangkan dalam kemasan eceran wajib mencantumkan label). Pelabelan yang baik memberikan informasi produk yang benar sehingga masyarakat dapat terhindar dari produk tidak layak dan tidak aman yang dapat menyebabkan dampak buruk terhadap kesehatan,

Korespondensi: tjahjamuhandri@apps.ipb.ac.id terhindar dari produk yang sudah kedaluwarsa, dan produk yang tidak halal bagi umat muslim.

Label juga berfungsi sebagai sarana untuk mengiklankan produk. Hal tersebut sangat bermanfaat bagi pelaku usaha dalam persaingan bisnis (Herudiansyah et al. 2019). Masyarakat akan semakin mudah memilih produk yang akan dibeli karena label dapat menjadi identitas produk. Beberapa konsumen cenderung tidak terlalu memerhatikan produk pangan yang tidak mencantumkan label karena informasi mengenai produk tidak tersampaikan dengan jelas (Darajat et al. 2016).

Pemberian label halal pada kemasan dapat menjadi strategi pemasaran produk dan peluang produsen untuk mendapatkan market share semakin meningkat (Astogini et al. 2011). Kesadaran masyarakat terhadap produk 
pangan yang bermutu dan aman juga meningkat, sehingga diperlukan informasi obyektif mengenai produk pangan yang hendak dikonsumsi. Informasi tersebut dapat membantu konsumen dalam memutuskan pangan yang akan dikonsumsi (Chotim dan Subhan 2014). Kesadaran masyarakat terhadap produk halal juga semakin meningkat. Peningkatan tersebut tidak sejalan dengan tindakan produsen dalam memberikan label halal pada produknya terutama pada produsen IRTP.

Meskipun peraturan mengenai pelabelan sudah dikeluarkan oleh pemerintah, namun masih dijumpai masalah dalam pelabelan khususnya pada produk IRTP. Label pangan pada produk IRTP masih sering dijumpai hanya mencantumkan nama atau merek dagangnya saja tanpa keterangan lain. Menurut hasil penelitian Wijaya dan Rahayu (2014), pemenuhan pelabelan pada produk IRTP di wilayah Bogor masih cukup rendah. Hanya $16 \%$ produsen IRTP yang memahami peraturan pelabelan tersebut.

Pemberian label halal pada produk IRTP juga masih sedikit dilakukan oleh pelaku usaha IRTP. Menurut Rohmah dan Iswantoro (2016), kendala yang sering dihadapi oleh produsen pangan dalam sertifikasi halal, yaitu hanya produsen yang menginginkannya saja yang mendaftar meskipun sertifikasi halal saat ini sudah bersifat wajib, kurangnya sosialisasi mengenai halal untuk industri kecil, serta prosesnya membutuhkan waktu lama dan biaya yang mahal.

Menurut data BPS Kebumen (2020), pada tahun 2018 jumlah industri yang ada di Kebumen mencapai 56.336 unit. Industri di bidang pangan menjadi industri dengan jumlah terbanyak di Kebumen yaitu 35.716 unit yang terdiri atas industri kecil hingga menengah. Jumlah tersebut meningkat dari tahun 2016 yang berjumlah 35.709 unit industri pangan (BPS Kebumen 2017). Kajian mengenai pemenuhan peraturan terhadap produk IRTP di Kebumen belum pernah dilakukan sebelumnya. Oleh karena itu, dilakukan penelitian mengenai tingkat kesesuaian pencantuman label produk IRTP dengan peraturan dari pemerintah.

\section{BAHAN DAN METODE}

\section{Bahan}

Perangkat peralatan pada penelitian ini berupa laptop yang telah terinstal aplikasi microsoft excel dan IBM SPSS 23, checksheet, serta kuesioner. Bahan yang diamati adalah label kemasan produk IRTP yang diproduksi dan beredar di wilayah Kabupaten Kebumen.

\section{Pengelompokan produk IRTP (Fransisca et al. 2016)}

Data mengenai banyaknya produk IRTP yang telah memiliki izin edar yang berasal dari Dinas Kesehatan Kabupaten Kebumen digunakan sebagai dasar untuk menetapkan jenis dan jumlah sampel produk IRTP yang diteliti. Jumlah minimum sampel yang diteliti, ditetapkan melalui perhitungan menggunakan rumus Slovin:

$$
\mathrm{n}=\frac{\mathrm{N}}{\left(1+\mathrm{Ne}^{2}\right)}
$$

dimana, $\mathrm{n}=$ Jumlah sampel; $\mathrm{N}=$ Total populasi; $\mathrm{e}=$ Tingkat toleransi dalam pengambilan sampel.

Berdasarkan data dari Dinas Kesehatan Kebumen hingga tahun 2020 terdapat 1215 produk IRTP yang telah memiliki nomor izin edar P-IRT sehingga dapat dihitung jumlah minimum produk IRTP menggunakan persamaan 1 dengan hasil $n=92.40 \approx 93$.

Jumlah sampel minimal sebanyak 93 sampel. Dalam penelitian ini ditetapkan sampel total (n) sebanyak 100 produk dari tiga jenis produk IRTP yang terdaftar paling banyak di Kebumen. Proporsi jenis produk IRTP ditetapkan dengan rumus:

$$
\mathrm{nk}=\frac{\mathrm{Nk}}{\mathrm{N}} \times \mathrm{n}
$$

dimana, $\mathrm{nk}=$ ukuran sampel kategori/jenis; $\mathrm{Nk}=$ ukuran populasi kategori/jenis; $\mathrm{N}=$ ukuran sampel total.

\section{Pengumpulan data (Siregar 2017)}

Data label produk IRTP diperoleh secara langsung di lapangan yaitu dari tempat perbelanjaan yang berada di Kabupaten Kebumen. Sebanyak 15 sampel diperoleh dari swalayan dan sebanyak 85 sampel diperoleh dari toko kelontong atau minimarket. Sampel diambil dengan teknik purposive sampling dengan pertimbangan tertentu, yaitu produk telah mencantumkan nomor izin edar P-IRT atau alamat IRTP adalah Kebumen. Informasi yang diperoleh dicatat pada checksheet.

\section{Analisis data (Siregar 2017)}

Analisis data survei label produk dilakukan dengan teknik content analysis dengan cara membandingkan hasil informasi yang diperoleh melalui pengamatan pada label kemasan produk dengan peraturan mengenai pelabelan yaitu Peraturan BPOM Nomor 31 Tahun 2018, PP RI Nomor 69 Tahun 1999, dan Peraturan BPOM RI Nomor HK.03.1.23.04.12.2206 Tahun 2012 Tentang CPPB-IRT. Komponen label yang dianalisis ada 4 kelompok unsur, yaitu teknis pencantuman label, tulisan pada label, keterangan minimum label, dan keterangan yang dilarang dicantumkan pada label kemasan. Hasil yang didapat kemudian dihitung tingkat pemenuhan (TP) persyaratan pelabelan menggunakan rumus berikut:

$$
\begin{aligned}
& \text { TP unsur }(\%)=\frac{\sum \text { produk yang memenuhi }}{\sum \text { total produk }} \times 100 \% \ldots \\
& \text { TP kelompok unsur }(\%)=\frac{\sum \text { total TP unsur }}{\sum \text { unsur label }} \ldots \ldots \ldots . \\
& \text { TP rata-rata }(\%)=\frac{\sum \text { TP kelompok unsur }}{\sum \text { kelompok unsur label }} \ldots \ldots \ldots . .
\end{aligned}
$$




\section{HASIL DAN PEMBAHASAN}

\section{Kelompok jenis produk IRTP}

Data dari Dinas Kesehatan Kabupaten Kebumen menyebutkan bahwa hingga akhir tahun 2020 terdapat 942 IRTP yang telah memiliki SPP-IRT dan terdapat 1215 produk IRTP telah memiliki izin edar P-IRT. Data tersebut menandakan adanya IRTP yang memproduksi lebih dari 1 jenis produk IRTP. Sebanyak 1215 produk yang telah terdaftar tersebut kemudian dikelompokkan berdasarkan 15 jenis pangan untuk produk IRTP (Gambar 1).

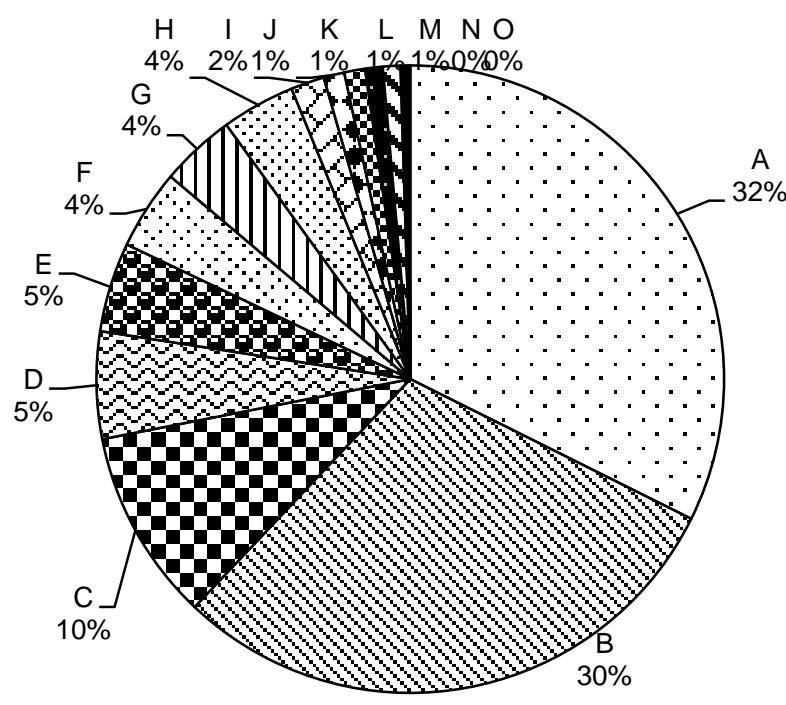

Keterangan: $A=$ Tepung dan hasil olahannya; $B=$ Hasil olahan bijibijian, kacang-kacangan, dan umbi; $\mathrm{C}=$ Hasil olahan buah; $\mathrm{D}=$ Gula, kembang gula, dan madu; $E=$ Bumbu; $F=$ Hasil olahan ikan kering; $\mathrm{G}=$ Hasil olahan sayur; $\mathrm{H}=$ Minuman serbuk; $\mathrm{I}=$ Kopi dan teh kering; $\mathrm{J}=$ Hasil olahan unggas kering; $\mathrm{K}=$ Hasil olahan kelapa; $\mathrm{L}=$ Hasil olahan daging kering. $\mathrm{M}=$ Minyak dan lemak. $\mathrm{N}=$ Rempahrempah; dan $\mathrm{O}=$ Selai, jeli, dan sejenisnya.

Gambar 1. Kelompok jenis produk IRTP di Kabupaten Kebumen

Berdasarkan Gambar 1, jenis produk yang dijadikan sampel pada penelitian ini, yaitu produk jenis tepung dan hasil olahannya (32\%); produk hasil olahan bijibijian, kacang-kacangan, dan umbi (30\%); serta produk hasil olahan buah (10\%), ketiga jenis produk IRTP tersebut memiliki jumlah persentase tertinggi di Kabupaten Kebumen. Sampel label kemasan yang digunakan pada penelitian ini berjumlah 100 sampel yang terdiri atas 3 jenis produk IRTP yang telah disebutkan. Ukuran populasi (Nk) jenis tepung dan hasil olahannya; hasil olahan biji-bijian, kacang-kacangan, dan umbi; serta hasil olahan buah masing-masing sebesar 393, 361, dan 120 produk (total 874 produk). Berdasarkan hasil perhitungan secara proporsional diperoleh ukuran sampel untuk masing-masing jenis produk pangan (nk) yang dapat dilihat pada Tabel 1 .

\section{Teknis pencantuman label}

Tata cara pencantuman label pangan telah diatur pada PP RI Nomor 69 Tahun 1999 tentang Label dan
Iklan Pangan serta peraturan terbaru PerBPOM Nomor 31 Tahun 2018 tentang Label Pangan Olahan. Hasil penelitian mengenai tingkat pemenuhan teknis pencantuman label kemasan pada masing-masing produk IRTP dapat dilihat pada Gambar 2. Tingkat pemenuhan produk hasil olahan biji-bijian, kacang-kacangan, dan umbi memiliki tingkat persentase tertinggi di antara produk lainnya yaitu sebesar $70.73 \%$. Kemudian, disusul produk tepung dan hasil olahannya sebesar $66.67 \%$ dan produk hasil olahan buah sebesar 64.29\%. Produk IRTP (100 buah sampel) dengan label yang menjadi bagian dari kemasan memiliki jumlah yang paling sedikit yaitu sebanyak 19\%, jumlah produk dengan label yang dimasukkan ke dalam kemasan (transparan) sebanyak 40\%, dan jumlah label yang ditempelkan pada bagian luar kemasan ada sebanyak $41 \%$.

Tabel 1. Jumlah sampel pada 3 jenis produk IRTP terbanyak di Kebumen

\begin{tabular}{lcc}
\hline Jenis Produk IRTP Terpilih & $\begin{array}{c}\text { Jumlah } \\
\text { Populasi (Nk) }\end{array}$ & $\begin{array}{c}\text { Jumlah } \\
\text { Sampel (nk) }\end{array}$ \\
\hline $\begin{array}{l}\text { Tepung dan hasil olahannya } \\
\text { Hasil olahan biji-bijian, }\end{array}$ & 393 & 45 \\
kacang-kacangan, dan umbi & 361 & 41 \\
Hasil olahan buah & 120 & 14 \\
\hline \multicolumn{1}{c}{ Total } & $\mathbf{8 7 4}$ & $\mathbf{1 0 0}$ \\
\hline
\end{tabular}

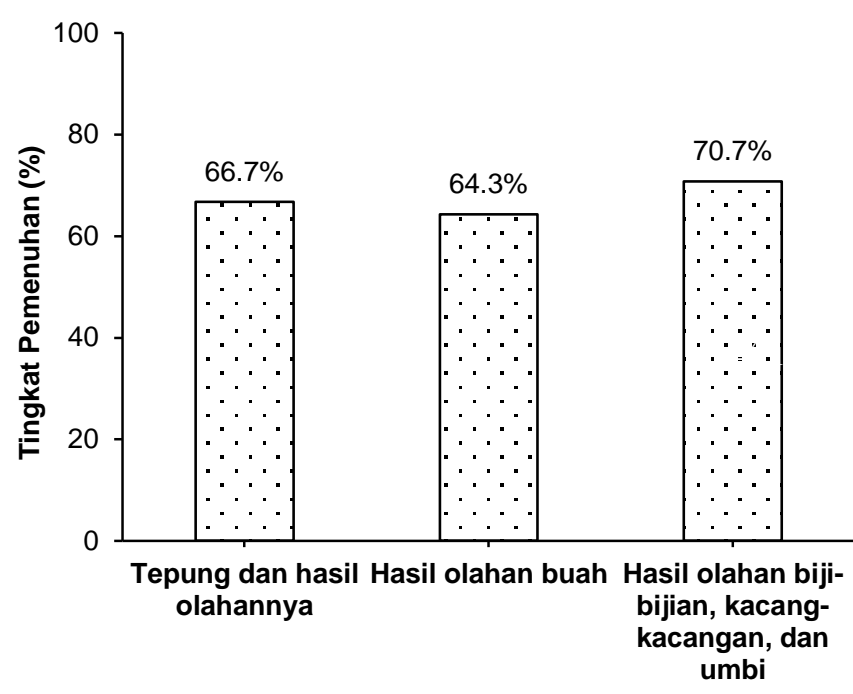

Gambar 2. Tingkat pemenuhan unsur teknis pencantuman label

Kesalahan pada unsur teknis pencantuman label kemasan produk IRTP yang sering ditemui (Gambar 3), yaitu sebanyak 12 produk (12\%) dari keseluruhan sampel memiliki label yang mudah terlepas dari kemasan. Hal tersebut dikarenakan produsen mencantumkan keterangan kedaluwarsa menggunakan label tersendiri yang ditempel secara terpisah dari label kemasan sehingga dapat dengan mudah dilepas atau dihilangkan. Terutama untuk produk dengan label yang ditempel pada bagian luar kemasan. Sebanyak 19 produk (19\%) dari kesalahan pada label yang labelnya dihapus, ditutup, diganti, atau dilabeli kembali (32\%) tidak mencantumkan keterangan kedaluwarsa sehingga tidak dapat diidentifikasi apakah label kedaluwarsa produk tersebut 
mudah dihapus atau dihilangkan. Terdapat kemungkinan jika keterangan kedaluwarsa produk tersebut sudah hilang akibat menggunakan label terpisah atau menggunakan tinta yang mudah luntur. Kesalahan lainnya seperti label yang mudah luntur atau rusak jika digosok menggunakan jari. Hal tersebut dikarenakan hasil cetak atau sablon pada kemasan yang kurang baik sehingga mudah dihilangkan apabila digosok menggunakan jari.

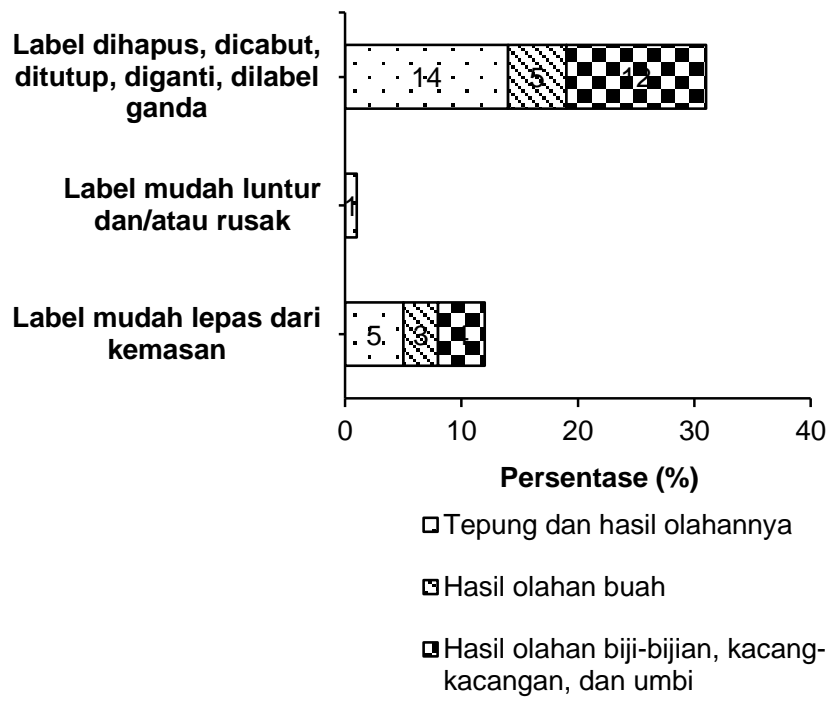

Gambar 3. Tingkat kesalahan teknik pencantuman label (100 produk)

\section{Tulisan pada label}

Kesesuaian teknis penulisan label pada produk yang diteliti memiliki hasil paling rendah di antara keempat kelompok unsur yang diamati (Gambar 4). Tingkat pemenuhan untuk unsur penggunaan bahasa Indonesia, angka Arab, dan huruf Latin memiliki persentase yang paling rendah di antara unsur lainnya pada kelompok teknis penulisan label. Sebanyak 12 dari 45 produk IRTP jenis tepung dan hasil olahannya yang memenuhi ketentuan (26.67\%); produk hasil olahan buah ada sebanyak 5 dari 14 produk telah memenuhi (35.71\%); dan hasil terendah pada produk hasil olahan biji-bijian, kacang-kacangan, dan umbi sebanyak 10 dari 41 produk yang memenuhi ketentuan $(24.39 \%)$. Secara keseluruhan $27 \%$ produk IRTP yang telah memenuhi pesyaratan tulisan pada label.

Kesalahan penggunaan bahasa yang kerap ditemui saat pengamatan yaitu banyak tulisan pada label yang menggunakan bahasa asing tanpa didahului dengan bahasa Indonesia. Bahasa asing yang sering ditemui yaitu bahasa Inggris dalam penulisan unsur berat bersih yang ditulis netto atau net weight, penulisan unsur kedaluwarsa expired date (EXP), dan keterangan lainnya seperti snack, product, new, best quality, home industry, barbeque, bakery, traditional food, dan special. Sebagian besar kesalahan penulisan diakibatkan oleh penulisan unsur berat bersih dan unsur kedaluwarsa. Keterangan lainnya yaitu ditemukan penggunaan istilah atau singkatan gaul jadoel pada produk jenis tepung dan hasil olahannya.

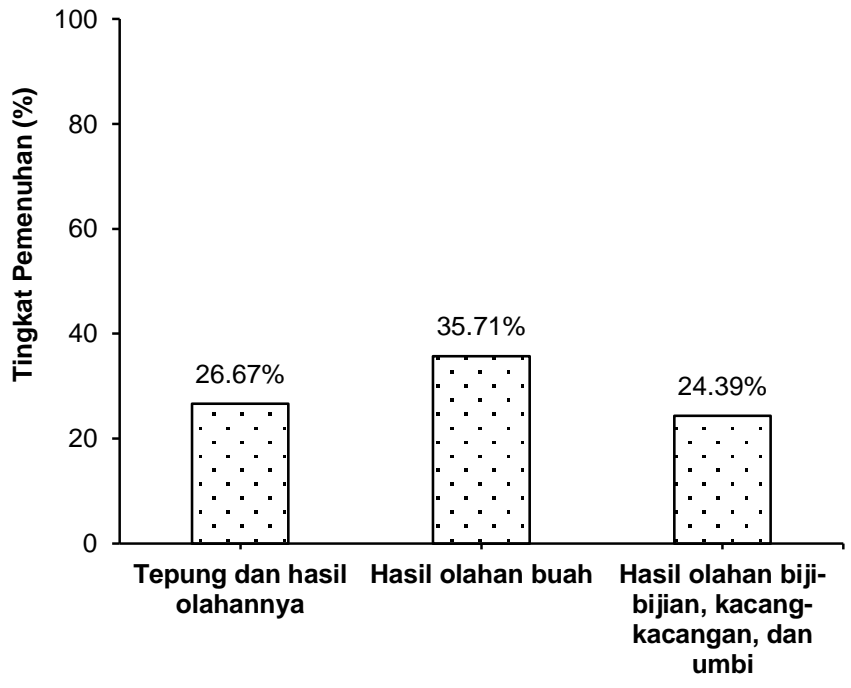

Gambar 4. Tingkat pemenuhan teknis penulisan label

Pasal 26 ayat (2) PerBPOM Nomor 31 Tahun 2018 dijelaskan bahwa ukuran berat untuk Pangan Olahan padat dinyatakan dengan berat bersih dan ukuran volume untuk Pangan Olahan cair dinyatakan dengan isi bersih. Penulisan ukuran yang tepat untuk ketiga jenis produk IRTP yang diteliti adalah berat bersih. Penggunaan istilah netto tidak tepat karena bukan bahasa Indonesia. Pasal 34 ayat (5) menyebutkan keterangan kedaluwarsa sebagaimana dimaksud pada ayat (1) didahului tulisan Baik digunakan sebelum. Penggunaan istilah expired date untuk menyatakan keterangan kedaluwarsa tidak tepat karena istilah tersebut merupakan bahasa asing. Sebagaimana disebutkan di dalam pasal 7 Peraturan BPOM Nomor 31 Tahun 2018 bahasa asing boleh digunakan asalkan didahului oleh bahasa Indonesia atau memang dikarenakan tidak ada padanan katanya dalam bahasa Indonesia.

Kriteria lain yang menjadi ketentuan dalam penulisan label yaitu desain untuk latar belakang tidak mengaburkan tulisan serta tulisan wajib dicantumkan secara jelas, mudah dibaca, dan proporsional dengan luas permukaan label. Hal tersebut tercantum pada pasal 8 dan pasal 9 PerBPOM Nomor 31 Tahun 2018. Hasil penelitian menunjukkan tingkat pemenuhan untuk unsur desain latar belakang sudah tinggi $(100 \%)$ karena tidak ditemui desain latar belakang yang mengaburkan tulisan.

\section{Keterangan minimum label}

Unsur-unsur label yang harus atau sekurang-kurangnya dicantumkan pada label disebut keterangan minimum label. Produk IRTP memiliki ketentuan tersendiri yang mengatur mengenai keterangan minimum label. Produk IRTP harus memuat sekurang-kurangnya 7 unsur label, di antaranya: a) nama produk; b) daftar bahan; c) berat bersih; d) nama dan alamat produsen; e) keterangan kedaluwarsa; f) tanggal dan kode produksi dan g) nomor P-IRT.

Selain tujuh unsur label tersebut, dilakukan pengamatan juga terhadap unsur keterangan halal. Namun, hasil dari analisis terhadap keterangan halal tidak 
dimasukkan ke dalam perhitungan tingkat pemenuhan kelompok unsur. Tujuan dari diamatinya keterangan halal pada sampel adalah untuk mengetahui sudah sejauh mana tingkat kesadaran produsen IRTP di Kebumen terhadap sertifikasi produk pangannya. Menurut Pasal 4 UU RI Nomor 33 Tahun 2014 tentang Jaminan Produk Halal, Produk yang masuk, beredar, dan diperdagangkan di wilayah Indonesia wajib bersertifikat halal. Berdasarkan pasal tersebut, sertifikasi halal menjadi wajib di Indonesia. Oleh karena itu, dapat diketahui pula kesiapan produsen IRTP dalam menghadapi peraturan tersebut.

Hasil pengamatan terhadap keterangan minimum label produk IRTP di Kabupaten Kebumen dapat dilihat pada Tabel 2. Kategori pangan IRT dengan tingkat pemenuhan tertinggi yaitu produk hasil olahan bijibijian, kacang-kacangan, dan umbi (44.25\%); diikuti produk jenis tepung dan hasil olahannya $(43.49 \%)$; dan terendah pada produk hasil olahan buah $(34.69 \%)$. Ratarata tingkat pemenuhan keterangan minimum label sekitar $40.81 \%$. Hasil yang kurang memenuhi ini disebabkan oleh adanya satu atau lebih unsur yang tidak dicantumkan pada label ataupun sudah dicantumkan, namun tidak sesuai dengan persyaratan pelabelan.

Tabel 2. Sebaran tingkat pemenuhan keterangan minimum label

\begin{tabular}{|c|c|c|c|}
\hline \multirow[b]{2}{*}{ Unsur Label } & \multicolumn{3}{|c|}{ Tingkat Pemenuhan (\%) } \\
\hline & $\begin{array}{c}\text { Tepung } \\
\text { dan Hasil } \\
\text { Olahannya } \\
(\mathrm{N}=45)\end{array}$ & $\begin{array}{c}\text { Hasil } \\
\text { Olahan } \\
\text { Buah }(\mathrm{N}= \\
14)\end{array}$ & $\begin{array}{l}\text { Hasil Olahan } \\
\text { Biji-Bijian, } \\
\text { Kacang- } \\
\text { Kacangan, } \\
\text { dan Umbi (N } \\
=41)\end{array}$ \\
\hline Nama produk & 86.67 & 71.43 & 90.24 \\
\hline Daftar bahan & 57.78 & 21.43 & 51.22 \\
\hline Berat bersih & 17.78 & 0.00 & 17.07 \\
\hline $\begin{array}{l}\text { Nama dan alamat } \\
\text { produsen }\end{array}$ & 4.44 & 0.00 & 2.44 \\
\hline $\begin{array}{l}\text { Keterangan } \\
\text { kedaluwarsa }\end{array}$ & 57.78 & 78.57 & 65.85 \\
\hline $\begin{array}{l}\text { Tanggal dan kode } \\
\text { produksi }\end{array}$ & 6.67 & 7.14 & 9.76 \\
\hline Nomor P-IRT & 73.33 & 64.29 & 73.17 \\
\hline Rata-rata (\%) & 43.49 & 34.69 & 44.25 \\
\hline
\end{tabular}

\section{Nama produk}

Hasil tingkat pemenuhan unsur nama produk dapat dilihat pada Tabel 2. Tingkat pemenuhan unsur nama produk oleh IRTP Kabupaten Kebumen terbilang cukup tinggi. Tingkat pemenuhan produk dengan persentase tertinggi hingga terendah berturut-turut adalah produk IRTP hasil olahan biji-bijian, kacang-kacangan, dan umbi (90.24\%); produk jenis tepung dan hasil olahannya (86.67\%); dan produk hasil olahan buah (71.43\%). Kesalahan yang ditemui saat pengamatan yaitu tidak mencantumkan salah satu dari nama jenis atau nama dagangnya. Produk hasil olahan buah yang tidak mencantumkan nama jenis ada satu produk dan tidak mencantumkan nama dagang ada tiga produk dari 14 produk yang diamati.

\section{Daftar bahan}

Daftar bahan terdiri atas bahan baku, bahan tambahan pangan (BTP), dan bahan penolong. Semua bahan yang digunakan dalam pembuatan produk pangan harus dicantumkan pada label kemasan (BPOM 2020). Tingkat pemenuhan produk dari persentase tertinggi hingga terendah yaitu produk jenis tepung dan hasil olahannya $(57.78 \%)$; produk hasil olahan biji-bijian, kacangkacangan, dan umbi (51.22\%); dan produk hasil olahan buah $(21.43 \%)$. Temuan terhadap kekurangan dari 100 produk adalah terdapat produk yang tidak mencantumkan komposisi bahan di label kemasan (16\%). Produk sudah mencantumkan komposisi, namun tidak sesuai dengan kriteria persyaratan unsur daftar bahan (33\%). Contohnya, pencantuman unsur daftar bahan tidak didahului dengan tulisan daftar bahan, bahan yang digunakan, bahan-bahan, atau komposisi; menggunakan singkatan (dan lain-lain); menuliskan nama bahan yang tidak diikuti asal bahan yang bersumber dari hewan atau tanaman (minyak sawit ditulis minyak saja, tepung terigu hanya ditulis tepung); bahan tidak dijabarkan dengan lengkap (hanya menuliskan bumbu atau seasoning); serta ada yang menuliskan dengan bahan pilihan atau resep khusus.

\section{Berat bersih}

Berat bersih atau isi bersih yang merupakan berat atau isi bersih dihitung tanpa wadah, ditulis menggunakan satuan metrik seperti gram (g), kilogram (kg), mililiter (mL), atau liter (L) (Hakim 2020). Tingkat pemenuhan unsur berat bersih produk IRTP di Kabupaten Kebumen yaitu produk tepung dan hasil olahannya sebesar 17.78\%; hasil olahan biji-bijian, kacang-kacangan, dan umbi $17.07 \%$; dan hasil olahan buah $0.00 \%$. Secara total, produk IRTP yang belum mencantumkan keterangan berat bersih (42\%). Produk yang telah mencantumkan berat bersih namun belum sesuai, seperti menggunakan singkatan gr untuk satuan gram (seharusnya disingkat g) (29\%), menggunakan satuan biji atau buah (4\%), tidak didahului dengan tulisan berat bersih (1\%), serta produk sudah diberi keterangan berat bersih namun tidak ada nominal berat yang dicantumkan (9\%).

\section{Nama dan alamat produsen}

Nama dan alamat produsen yang memenuhi ketentuan pelabelan pada produk jenis tepung dan hasil olahannya sebesar 4.44\%; produk hasil olahan buah sebesar $0.00 \%$; serta produk hasil olahan biji-bijian, kacang-kacangan, dan umbi sebesar $2.44 \%$. Sebenarnya produsen telah mencantumkan nama dan alamat pada label kemasan produknya, namun penulisannya tidak sesuai dengan ketentuan. Sebagian besar produsen menuliskan alamat berupa desa dan kabupaten saja, tanpa kode pos dan negara. Ada beberapa produsen yang telah menuliskan kabupaten dan negaranya saja. Nama dan alamat seharusnya dicantumkan dengan lengkap sesuai dengan peraturan yang mengaturnya. Hal tersebut karena nama dan alamat produsen merupakan identitas pelaku usaha yang berperan penting sebagai bentuk 
pertanggungjawaban dari produsen apabila terjadi hal yang tidak diinginkan (Hakim 2020).

\section{Keterangan kedaluwarsa}

Hasil yang diperoleh dari pengamatan terhadap produk IRTP jenis tepung dan hasil olahannya memiliki persentase tingkat pemenuhan sebesar $57.78 \%$; produk hasil olahan buah sebesar $78.57 \%$; dan produk hasil olahan biji-bijian, kacang-kacangan, dan umbi sebesar $65.85 \%$. Kesalahan dalam pencantuman keterangan kedaluwarsa yang ditemui saat pengamatan antara lain, produk tidak mencantumkan keterangan kedaluwarsa (18\%), produk sudah mencantumkan keterangan kedaluwarsa namun tidak diberi tanda atau diberi nominal angka yang menunjukkan tanggal-bulan-tahun (13\%), serta ditemui pula pencantuman waktu kedaluwarsa tanpa didahului tulisan baik digunakan sebelum atau keterangan lain yang semakna $(5 \%)$.

Pencantuman waktu kedaluwarsa meliputi tanggal, bulan, dan tahun (BPOM 2018), atau cukup bulan dan tahun untuk (kedaluwarsa produk > 3 bulan). Terdapat produk pangan yang mendapat pengecualian, yaitu produk minuman yang mengandung minimal $7 \%$ alkohol, cuka, dan roti atau kue yang masa simpannya maksimal 24 jam. Meskipun dikecualikan dari ketentuan kedaluwarsa, namun tetap harus mencantumkan tanggal produksi atau tanggal pengemasan. Istilah tanggal kedaluwarsa atau gunakan sebelum (use by atau expired date) memiliki makna bahwa konsumen dapat mengonsumsi produk pangan maksimal pada waktu kedaluwarsa yang tertera. Setelah melewati batas waktu, maka kualitas produk dari segi mutu maupun keamanan diduga tidak dapat diterima lagi oleh konsumen. Biasanya produkproduk yang mudah rusak yang menggunakan istilah tersebut, seperti produk daging dan susu (Vicky 2014).

\section{Tanggal dan kode produksi}

Kode produksi berupa angka, huruf, atau tanggal produksi untuk menunjukkan riwayat pembuatan produk pangan. Hasil pengamatan diperoleh data tingkat pemenuhan yang cukup rendah. Persentase dengan nilai terendah yaitu produk IRTP jenis tepung dan hasil olahannya sebesar $6.67 \%$, kemudian produk hasil olahan buah sebesar $7.14 \%$, dan persentase tertinggi yaitu produk hasil olahan biji-bijian, kacang-kacangan, dan umbi sebesar $9.76 \%$. Kesalahan yang ditemukan yaitu masih banyak produsen yang tidak mencantumkan kode produksi pada label kemasannya (83\%). Ada pula yang telah mencantumkan keterangan kode produksi namun tidak diisi dengan kode maupun tanggal produksinya (9\%). Hal ini dimungkinkan karena produsen kurang peduli dan masih belum paham dengan maksud pemberian kode produksi. Pemberian kode produksi sebenarnya mempermudah produsen dalam memantau produknya di pasaran. Jika terjadi hal yang tidak diinginkan dan mengharuskan produk ditarik dari peredaran, maka tidak harus semua produk ditarik. Produk dengan kode tertentu saja yang ditarik. Hal tersebut dapat mencegah kerugian yang terlalu besar (Chotim dan Subhan 2014).

\section{Nomor P-IRT}

Produk pangan yang memiliki nomor izin edar, tandanya produk pangan sudah terdaftar dan sudah bisa diedarkan di wilayah Indonesia (Hakim 2020). Seluruh produk IRTP yang diamati pada penelitian ini sudah memiliki nomor P-IRT. Namun, tingkat pemenuhannya belum $100 \%$, produk hasil olahan buah sebesar $64.29 \%$; hasil olahan biji-bijian, kacang-kacangan, dan umbi sebesar 73.17\%; dan produk jenis tepung dan hasil olahannya sebesar $73.33 \%$. Kesalahan pencantuman nomor P-IRT antara lain, ditemukan nomor P-IRT yang kurang dari 15 digit, ditemukan pula nomor P-IRT yang sudah tidak berlaku atau sudah melewati batas tahun berlakunya, serta terdapat nomor P-IRT yang tidak sesuai dengan jenis atau kategori produknya. Nomor PIRT dapat digunakan oleh produsen IRTP untuk produk lainnya yang sejenis atau memiliki bahan baku yang sama (BPOM 2018). Contohnya, nomor P-IRT yang diperoleh produk emping jagung dapat digunakan untuk produk yang berbahan baku jagung, seperti kerupuk jagung atau marning jagung. Jika menggunakan bahan baku yang berbeda, maka produsen pangan IRT harus mendaftarkan kembali produknya (Wulandari dan Deliana 2020).

\section{Keterangan halal}

Berkembangnya teknologi pengolahan pangan, seperti pengawetan, fermentasi, bahkan rekayasa genetik menjadikan penentuan halal sebagai sesuatu yang penting. Oleh sebab itu, jaminan halal perlu dilakukan (Faidah 2017). Keterangan halal pada produk pangan ditandai dengan adanya logo halal yang terverifikasi oleh MUI. Pelaku usaha atau produsen khususnya di bidang pangan wajib mendaftarkan produknya ke BPJPH untuk sertifikasi halal dan memperoleh perizinan agar dapat mencantumkan logo halal pada label kemasannya (Wulansari dan Anggraini 2018). Data mengenai sebaran pencantuman keterangan halal pada produk IRTP yang diteliti dapat dilihat pada Tabel 3.

\begin{tabular}{lccc} 
Tabel 3. Sebaran pencantuman keterangan halal \\
\cline { 2 - 4 } \begin{tabular}{l} 
Jenis Pangan \\
\cline { 2 - 4 }
\end{tabular} & $\begin{array}{c}\text { Logo Halal } \\
\text { Tersertifikasi } \\
\text { MUl }\end{array}$ & $\begin{array}{c}\text { Logo Halal } \\
\text { Tidak Terser- } \\
\text { tifikasi MUl }\end{array}$ & $\begin{array}{c}\text { Tidak ada } \\
\text { Logo } \\
\text { Halal }\end{array}$ \\
\hline $\begin{array}{l}\text { Tepung dan } \\
\text { hasil } \\
\text { olahannya } \\
\begin{array}{l}\text { Hasil olahan } \\
\text { buah }\end{array}\end{array}$ & 6 & 2 & 37 \\
$\begin{array}{l}\text { Hasil olahan } \\
\text { biji-bijian, } \\
\text { kacang- } \\
\text { kacangan, dan } \\
\text { umbi }\end{array}$ & 3 & 1 & 10 \\
\hline Total & 9 & 1 & 31 \\
\hline
\end{tabular}

Berdasarkan data di atas, hanya ada 5\% produk IRTP yang memenuhi syarat pencatuman halal. Sebanyak $95 \%$ tidak memenuhi syarat pencatuman halal dengan rincian $9 \%$ sudah habis masa berlakunya, $8 \%$ menggunakan logo halal tidak resmi $(8 \%)$ yaitu menggunakan tulisan halal dalam bahasa Indonesia atau 
bahasa Arab dan 78\% tidak mencatumkan label halal. Masih banyaknya produk IRTP yang belum mencantumkan logo halal tersertifikasi MUI dimungkinkan karena produsen melihat dari segi biaya yang tidak sebanding dengan pemasukan serta menganggap produknya sudah halal jika dilihat dari bahan yang digunakan sehingga tidak memerlukan sertifikasi halal (Nikmah et al. 2018).

Menurut Septian dan Rahayu (2014), produsen pangan IRT belum memahami prosedur untuk mencantumkan logo halal pada produknya. Konsumen cenderung lebih memerhatikan label halal pada produk impor karena kurang yakin dengan kehalalan bahan yang digunakan (Iriani 2019). Beda halnya dengan produk IRTP, konsumen cenderung sudah mengetahui bahan baku pembuatannya. Hal tersebut juga disebutkan pada penelitian Qomaro et al. (2019), produsen menyatakan bahwa konsumen tetap puas walaupun produknya tidak mencantumkan label halal.

\section{Pencantuman keterangan yang dilarang pada label}

Produk IRTP dilarang untuk mencantumkan klaim kesehatan atau klaim gizi pada label kemasannya. Beberapa hal yang dilarang untuk dicantumkan pada label pangan, seperti keterangan yang tidak benar dan menyesatkan; pangan memiliki fungsi seperti obat; keterangan ketiadaan suatu komponen yang secara alami memang tidak ada dalam produk; keterangan produk pangan sintetik berasal dari alam; keterangan lembaga yang menganalisis produk; keterangan yang menyinggung suku, agama, ras, dan/atau golongan tertentu; keterangan yang tidak terkait dengan pangan; dan keterangan tanpa BTP yang tidak sesuai dengan peraturan (BPOM 2018).

Tingkat pemenuhan pada kelompok unsur label ini terbilang tinggi hingga mencapai $90 \%$ untuk masingmasing jenis produk IRTP. Produk jenis tepung dan hasil olahannya memiliki nilai persentase pemenuhan sebesar $96.30 \%$; produk hasil olahan buah memiliki nilai persentese tertinggi sebesar $97.62 \%$; dan produk hasil olahan biji-bijian, kacang-kacangan, dan umbi memiliki nilai persentase terendah sebesar $95.12 \%$. Hasil pengamatan tingkat pemenuhan label untuk kelompok unsur keterangan yang dilarang dicantumkan pada label dapat dilihat pada Tabel 4.

Keterangan yang tidak benar dan menyesatkan memiliki nilai persentase pemenuhan yang paling ren- dah untuk ketiga jenis produk yang diamati. Hal ini menunjukkan banyak ketentuan yang dilanggar pada unsur label tersebut. Produk hasil olahan buah memiliki hasil tertinggi (78.57\%); dilanjutkan produk jenis tepung dan hasil olahannya (75.56\%); dan hasil terendah pada produk hasil olahan biji-bijian, kacang-kacangan, dan umbi (68.29\%). Label yang memuat keterangan mengenai mutu produk, seperti alami, murni, 100\%, dengan (diikuti nama bahan), dari (diikuti nama bahan), segar, dan asli, yang tidak sesuai dengan ketentuan, maka produk dinyatakan tidak memenuhi kriteria pemenuhan pelabelan. Kesalahan yang ditemukan saat pengamatan yaitu mencantumkan kata spesial, bergizi, super, higienis, pilihan, top choice, premium, terbuat dari bahan pilihan, $100 \%$ gula murni, sehat, mutu terjamin, resep khusus, best quality, dan alami.

Unsur keterangan yang tidak terkait dengan pangan menjadi hasil terendah kedua. Label dengan logo atau keterangan lain yang tidak berkaitan dengan produk pangan olahan atau berlebihan dikatakan tidak memenuhi unsur label ini. Label produk yang tidak memenuhi yaitu label produk jenis tepung dan hasil olahannya $(93.33 \%)$ serta produk hasil olahan biji-bijian, kacangkacangan, dan umbi $(90,24 \%)$. Sebanyak tiga dari 45 produk jenis tepung dan hasil olahannya serta empat dari 41 produk hasil olahan biji-bijian, kacang-kacangan, dan umbi yang diamati menyantumkan keterangan yang tidak berhubungan dengan produk pangan itu sendiri. Contohnya, ditemukan kalimat "rezeki untuk berbagi", "ringan dikantong", "pedas tapi sayang kalau berhenti", "see and feel difference taste", "move on", "barokah", dan terdapat gambar kartun tikus.

Kesalahan lainnya yaitu pada unsur keterangan tanpa BTP karena terdapat label yang tidak sesuai dengan ketentuan untuk produk jenis tepung dan hasil olahannya $(97.78 \%)$ serta produk hasil olahan bijibijian, kacang-kacangan, dan umbi $(97.56 \%)$. Terdapat 8 dari 100 produk IRTP yang menyantumkan keterangan tanpa BTP. Terdapat 1 produk dari masing-masing produk jenis tepung dan hasil olahannya serta hasil olahan biji-bijian, kacang-kacangan, dan umbi yang pemenuhannya tidak sesuai, yaitu mencantumkan keterangan tanpa pengembang dan tanpa pewarna serta tanpa penyedap rasa.

Tabel 4. Tingkat pemenuhan produk IRTP tanpa keterangan yang dilarang

\begin{tabular}{clccc}
\hline \multirow{2}{*}{ No } & Unsur Label & \multicolumn{3}{c}{ Tingkat Pemenuhan (\%) } \\
\cline { 3 - 5 } & & $\begin{array}{c}\text { Produk 06 } \\
(\mathbf{n = 4 5})\end{array}$ & $\begin{array}{c}\text { Produk 14 } \\
(\mathbf{n = 1 4})\end{array}$ & $\begin{array}{c}\text { Produk 15 } \\
(\mathbf{n}=\mathbf{4 1})\end{array}$ \\
\hline 1 & Klaim kesehatan atau klaim gizi & 100.00 & 100.00 & 100.00 \\
2 & Keterangan yang tidak benar dan menyesatkan & 75.56 & 78.57 & 68.29 \\
3 & Pangan dapat menyehatkan atau dapat berfungsi sebagai obat & 100.00 & 100.00 & 100.00 \\
4 & Keterangan ketiadaan suatu komponen & 100.00 & 100.00 & 100.00 \\
5 & Keterangan pangan berasal dari alam & 100.00 & 100.00 & 100.00 \\
6 & Keterangan lembaga yang menganalisis produk & 100.00 & 100.00 & 100.00 \\
7 & Keterangan yang menyinggung suku, agama, ras, dan/atau & 100.00 & 100.00 & 100.00 \\
& golongan tertentu & & \\
8 & Keterangan yang tidak terkait dengan pangan & 93.33 & 100.00 & 90.24 \\
9 & Keterangan tanpa BTP & 97.78 & 100.00 & 97.56 \\
\hline Rata-rata (\%) & $\mathbf{9 6 . 3 0}$ & $\mathbf{9 7 . 6 2}$ & $\mathbf{9 5 . 1 2}$ \\
\hline
\end{tabular}

Keterangan: Produk 06= Produk IRTP jenis tepung dan hasil olahannya; Produk 14= Produk IRTP hasil olahan buah; Produk 15= Produk IRTP hasil olahan biji-bijian, kacang-kacangan, dan umbi; $n=$ jumlah sampel produk 
BTP yang diizinkan untuk dicantumkan keterangan tanpa BTP pada label antara lain, pemanis buatan, pengawet, pewarna sintetik, antioksidan, dan/atau penguat rasa (BPOM 2018). BTP pengembang tidak termasuk ke dalam BTP yang diizinkan pada unsur keterangan tanpa BTP. BTP pewarna masuk kedalam kelompok BTP yang disebutkan di atas, namun pasal 24 ayat (4) pada peraturan yang sama menyebutkan pewarna yang dicantumkan pada label adalah tanpa pewarna sintetik. Ketentuan mengenai BTP penyedap rasa sama seperti BTP pewarna, seharusnya yang dicantumkan pada label yaitu tanpa penguat rasa. Penggunaan nama Jenis BTP, keterangan bebas BTP, tidak menggunakan BTP, tidak menambahkan BTP, tidak terdapat BTP, tidak mengandung BTP, atau yang semakna juga tidak diperkenankan. Misalnya mencantumkan keterangan bebas MSG pada label, seharusnya yang benar tanpa penguat rasa.

\section{Tingkat pemenuhan pelabelan rata-rata}

Perbandingan persentase rata-rata tingkat pemenuhan pelabelan dapat dilihat pada Gambar 6. Kelompok unsur keterangan yang dilarang dicantumkan pada label memiliki tingkat pemenuhan tertinggi untuk ketiga jenis produk IRTP di antara kelompok unsur lainnya. Tingkat pemenuhan dengan nilai terendah dimiliki oleh kelompok unsur tulisan pada label untuk produk jenis tepung dan hasil olahannya serta pada jenis produk hasil olahan biji-bijian, kacang-kacangan, dan umbi. Tingkat pemenuhan rata-rata dari ketiga jenis produk IRTP memiliki nilai persentase yang hampir sama. Sebesar $58 \%$ untuk produk jenis tepung dan hasil olahannya serta hasil olahan buah. Sebanyak 59\% untuk jenis produk hasil lahan biji-bijian, kacang-kacangan, dan umbi. Hasil yang diperoleh relatif rendah karena masih banyak label yang tidak sesuai dengan ketentuan pada peraturan yang mengatur mengenai pelabelan. Hal ini dimungkinkan karena peraturan yang dijadikan pedoman masih peraturan lama yaitu PP RI Nomor Nomor 69 tahun 1999 tentang Label dan Iklan Pangan. PerBPOM Nomor 31 Tahun 2018 memiliki masa peralihan 30 bulan sejak peraturan tersebut diundangkan.

Peran pemerintah menjadi penting sebagai pihak yang memberikan penyuluhan atau sosialisasi kepada produsen IRTP terkait adanya kebijakan pelabelan. Produsen IRTP juga dapat menyesuaikan dan melengkapi pencantuman atribut untuk menciptakan pangan yang aman (Nikmah et al. 2018). Label yang baik dapat memberikan informasi produk yang jelas kepada konsumen. Apabila terjadi pelanggaran dalam ketentuan pelabelan pada Peraturan BPOM Nomor 31 Tahun 2018, maka terdapat sanksi administratif: penghentian sementara dari kegiatan produksi, penarikan produk pangan dari peredaran, atau pencabutan izin produksi.

\section{KESIMPULAN}

Produk pangan industri rumah tangga yang paling banyak diproduksi di Kabupaten Kebumen berturut-turut adalah produk jenis tepung dan hasil olahannya (32\%); produk hasil olahan biji-bijian, kacang-kacangan, dan umbi (30\%); serta produk hasil olahan buah (10\%). Tingkat pemenuhan aturan pelabelan terbilang cukup rendah yang menandakan masih ditemui kesalahan pelabelan oleh produsen. Unsur label yang memiliki tingkat pemenuhan terendah yaitu pada kelompok unsur tulisan pada label, masih banyak produk yang tidak memerhatikan penulisan label menggunakan bahasa Indonesia yang benar. Adapun unsur label dengan tingkat pemenuhan tertinggi yaitu pada kelompok unsur keterangan yang dilarang dicantumkan pada label. Sebanyak 27\% produk IRTP memenuhi persyaratan tulisan pada label dan $40.81 \%$ memenuhi persyaratan keterangan minimum label (di luar ketentuan halal).

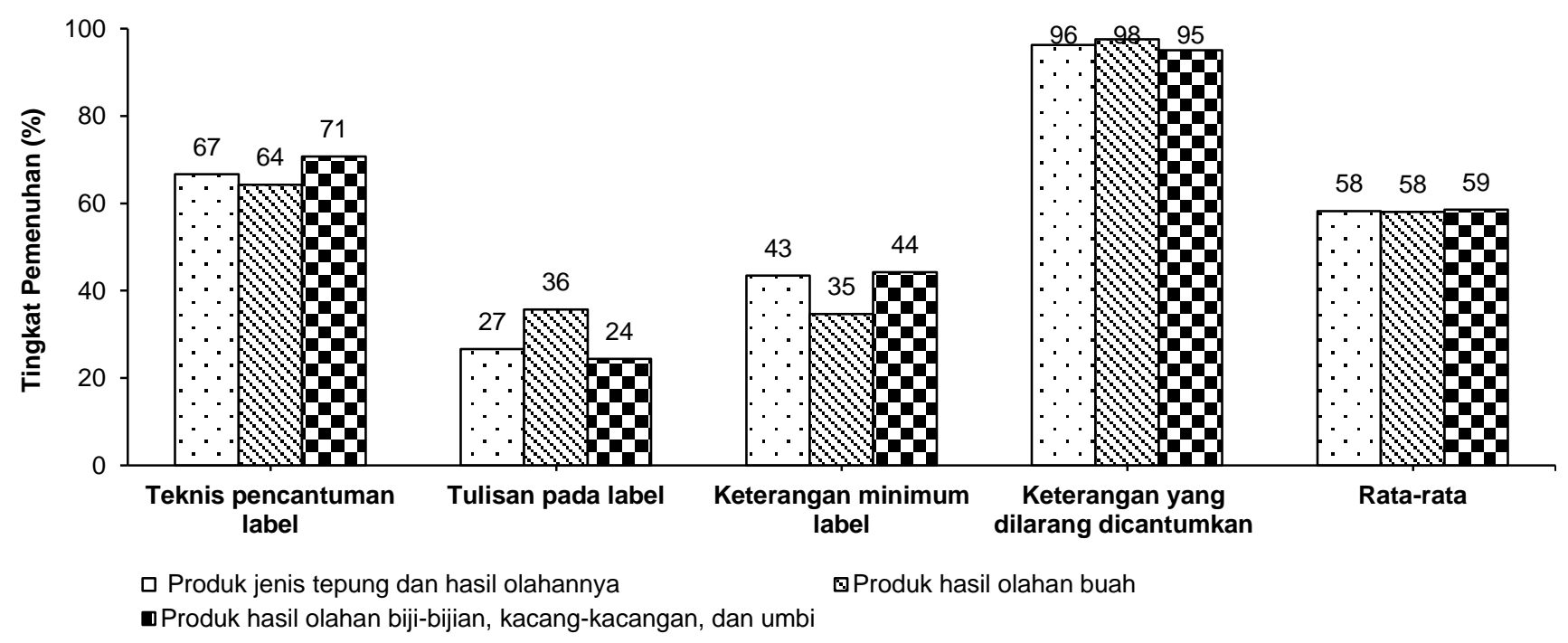

Gambar 5. Perbandingan tingkat pemenuhan label rata-rata (100 produk) 
Hal tersebut menunjukkan kurangnya pemahaman produsen terhadap pentingnya label pangan, produsen tidak terlalu memerhatikan ketentuan label pangan, serta masih menggunakan peraturan lama. Keterangan halal yang dicantumkan pada produk IRTP juga masih sedikit. Hanya ditemui 18 dari 100 produk yang telah mencantumkan logo halal tersertifikasi MUI. Masih banyak produsen IRTP (78\%) yang belum mencanumkan label halal pada kemasannya.

\section{DAFTAR PUSTAKA}

Astogini D, Wahyudin W, Wulandari SZ. 2011. Aspek religiusitas dalam keputusan pembelian produk halal (Studi tentang labelisasi halal pada produk makanan dan minuman kemasan). J Ekonomi, Bisnis, Akuntansi 13(1): 1-8. DOI: 10.32424/jeba.v13i1. 345.

[BPOM] Badan Pengawas Obat dan Makanan. 2018. Nomor 31 Tahun 2018 Tentang Label Pangan Olahan. Jakarta: Badan Pengawas Obat Dan Makanan.

[BPOM RI] Badan Pengawas Obat dan Makanan Republik Indonesia. 2020. Pedoman Label Pangan Olahan. Jakarta: Badan Pengawas Obat Dan Makanan RI.

[BPS Kebumen] Badan Pusat Statistik Kebumen 2020. Kabupaten Kebumen dalam Angka 2020. Kebumen: BPS Kabupaten Kebumen.

Chotim M, Subhan M. 2014. Evaluasi penulisan label pangan yang tidak lengkap dan iklan pangan menyesatkan pada industri rumah tangga pangan di Kabupaten Temanggung tahun 2013. J Riset Manajemen 1(1): 78-92. DOI: 10.32477/jrm.v1i1. 245.

Darajat N, Bahar H, Jufri NN. 2016. Hubungan kepatuhan membaca label informasi zat gizi dengan kemampuan membaca label informasi gizi pada ibu rumah tangga di Pasar Basah Mandonga Kota Kendari Tahun 2016 (Studi kasus pada UD. Puteri Kembar Kendari). J Ilmiah Mahasiswa Kesehatan Masy 1(4): 1-11. DOI: 10.37887/jimkesmas.v1i4. 1735.

Faidah M. 2017. Sertifikasi halal di Indonesia dari civil society menuju relasi kuasa antara negara dan agama. ISLAMICA: J Studi Keislaman 11(2): 449476. DOI: 10.15642/islamica.2017.11.2.449-476.

Fransisca, Palupi NS, Faridah DN. 2016. Persepsi konsumen dalam menentukan keputusan pembelian produk minuman dengan klaim kurang gula. J Mutu Pangan 3(1): 50-57.

Hakim AR. 2020. Perlindungan konsumen terhadap peredaran produk makanan dan minuman tanpa label. J Yustitiabelen 6(2): 98-110.
Herudiansyah G, Candera M, Pahlevi R. 2019. Penyuluhan pentingnya label pada kemasan produk dan pajak pada usaha kecil menengah (UKM) Desa Tebedak II Kecamatan Payaraman Ogan Ilir. Suluh Abdi: J Ilmiah Pengabdian Kepada Masy 1(2): 84-89.

Iriani SS. 2019. The effect of religiosity on the purchasing decision of halal labeled food product. East African Scholars J Econ Bus Manag 2(10): 621-628.

Nikmah ZC, Yudhastuti R, Dewi DMSK. 2018. Penerapan label pangan pada produk bagiak oleh produsen di Banyuwangi. J Kesehatan Masyarakat 17(02): 184-196.

Qomaro GW, Hammam H, Nasik K. 2019. Pemberdayaan usaha mikro kecil dan menengah sektor pangan dalam meningkatkan perekonomian lokal melalui pendampingan sertifikasi halal di Kecamatan Tragah Bangkalan. J Ilmiah Pangabdhi 5(2): 137142. DOI: 10.21107/pangabdhi.v5i2.6116.

Rohmah UA, Iswantoro I. 2016. Perlindungan hukum terhadap konsumen produk makanan yang tidak berlabel halal di Daerah Istimewa Yogyakarta tahun 2015. Supremasi Hukum: J Kajian Ilmu Hukum 5(2): 224-249.

Septian J, Rahayu WP. 2014. Pengetahuan pelabelan produsen industri rumah tangga pangan di Kota Bogor. J Mutu Pangan 1(2): 145-150.

Siregar S. 2017. Metode Penelitian Kuantitatif. Ed ke-4. Jakarta (ID): Kencana.

Vicky FT. 2014. Kajian hukum perlindungan konsumen terhadap produk pangan kadaluarsa. J Hukum Unsrat 2(2): 93-104.

Wijaya WA, Rahayu WP. 2014. Pemenuhan peraturan pelabelan produk industri rumah tangga pangan (IRTP) di Bogor. J Mutu Pangan 1(1): 65-73.

Wulandari E, Deliana Y. 2020. Peningkatan kualitas produk mangga kering dengan teknik dehidrasi osmosis di Kabupaten Indramayu. Dharmakarya: J Apl Ipteks Masy 9(1): 55-58. DOI: 10.24198/ dharmakarya.v9i1.19685.

Wulansari H, Anggraini AMT. 2018. Perlindungan konsumen terhadap ketiadaan label halal pada produk farmasi menurut undang-undang nomor 33 tahun 2014 tentang jaminan produk halal. J Hukum Adigama 1(1): 1-24. DOI: 10.24912/adigama.v1i1. 2186.

JMP-07-21-05-Naskah diterima untuk ditelaah pada 3 Februari 2021. Revisi makalah disetujui untuk dipublikasi pada 31 Maret 2021. Versi Online: http://journal.jpb.ac.id/ index.php/jmpi 